\title{
Proceeding
}

Supplementary Issue: Winter Conferences of Sports Science. Costa Blanca Sports Science Events, 25-26 January 2019.

Alicante, Spain

\section{Physical and motor tests to estimate the improvement of the float serve}

\author{
CIRO ALMINNI ${ }^{1} \triangleleft$, GAETANO ALTAVILLA ${ }^{2}$, FRANCESCO PELUSO CASSESE ${ }^{3}$, ANDREA CECILIANI ${ }^{4}$, \\ TIZIANA D'ISANTO1 \\ 1 University of Salerno, Italy \\ 2 University of Split, Croatia \\ 3 University of Niccolò Cusano of Rome, Italy \\ ${ }^{4}$ University of Bologna, Italy
}

\begin{abstract}
The aim of the study was to analyze and evaluate the differences in jumping ability and in the fundamental technical of the float serve in volleyball, in order to evaluate the effectiveness of a working method. The study was performed on a sample of 11 male volleyball players (Under 20). Data were collected in two periods (September and October), subjecting the players to intensive technical and physical work. At the beginning of the training period, anthropometric data were collected, such as mean and standard deviation, and jumping ability. Players made a series of float serve to a specific area of the opponent's field and incremental effects were estimated after the intensive training period (in October). The statistical analysis of the data provided for the estimation of the percentage data and a Test $t$ student to verify the difference between pre and post workout. The significant difference was set with $p<0.05$. The results show, after four weeks of intensive training, an improvement in jumping ability, at the Vertec test, equal to $3.45 \mathrm{~cm}$ and a significant difference with $p=0.001$, between the two series of jumps; while the estimate of the effect of technical training (float service) was $22 \%$. These physical and motor tests allow the training process to be monitored by estimating the effects induced, allowing the coaches to design and adequately choose the methodology and the training load for an effective performance. Key words: Volleyball; Jump test; Intensive training; Performance.
\end{abstract}

\section{Cite this article as:}

Alminni, C., Altavilla, G., Cassese, F.P., Ceciliani, A., \& D'Isanto, T. (2019). Physical and motor tests to estimate the improvement of the float serve. Journal of Human Sport and Exercise, 14(2proc), S245S250. doi:https://doi.org/10.14198/ihse.2019.14.Proc2.13

Corresponding author. University of Salerno, Italy.

E-mail: alminni2013@gmail.com

Supplementary Issue: Winter Conferences of Sports Science. Costa Blanca Sports Science Events, 25-26 January 2019. Alicante, Spain.

JOURNAL OF HUMAN SPORT \& EXERCISE ISSN 1988-5202

(c) Faculty of Education. University of Alicante.

doi:10.14198/jhse.2019.14.Proc2.13 


\section{INTRODUCTION}

The movement is fundamental for a child's physical (Valentini et al, 2018), cognitive and social development (Altavilla \& Di Tore, 2016); in addition, experiences support learning and development of fundamental movement skills (D'Isanto, 2016). The Physical activity, motor and sports should be the centre of the teaching-learning processes (D'Elia, 2019) and the process of construction of skills (Altavilla et al, 2018). It is widespread (Di Tore \& Raiola, 2012ab), in the sport and in volleyball (Ferrara et al, 2018), to test an athlete, can be said to be indispensable for several reasons. The first allows us to evaluate its potential, its athletic and technical qualities (Cirillo et al, 2016; D'Isanto et al, 2019), for example, for a particular skill needed during an intensive sports game such as a volleyball serve (Altavilla \& Raiola, 2018). The second to set up a correct training methodology (D'Isanto et al, 2017; Raiola, 2017; Raiola \& Di Tore, 2017; Raiola, 2014) and the third to verify and monitor the effectiveness of training (Raiola et al. al, 2013) and changes in physical condition (Forte \& Altavilla, 2018). Both for a coach and for an athlete it is very important to periodically monitor the results of his training programs (Raiola \& D'isanto, 2016). The tests are, above all for the technician, a fundamental periodic control tool (D'Isanto et al, 2018) very effective and thanks to the analysis of its results and the feedback received it is possible to relate the performance with the working strategies adopted (Altavilla et al, 2017) and consequently identify what may be the best adaptations to be made to the training program that is being administered to their athletes. The study wants to analyse and evaluate the ability to jump (Altavilla et al, 2018), explosive actions are elements of success (Altavilla \& Raiola, 2019) and technical skills in the fundamental of service in volleyball team (Raiola et al, 2016), verifying the effects induced after a 4-week training period. The float serve is generally performed with both feet on the ground or with a little jump and it is expected that with this technique the ball becomes charged with effect: in this way, while traveling to get into the other field, it will change slightly trajectory and will become difficult to receive. This happens because when the ball is hit the ball does not give any rotational effect on it, and when the initial thrust becomes less strong (when it comes close to the opponent's receiver), the air friction and the weight of the valve inflation make the ball move unpredictably. In the case in which the jump is performed, this type of bar is called "jump float". The jump allows you to go to hit the ball as high as possible, making it its trajectory tense and difficult to receive. It is performed by striking the ball and immediately pulling away the hand. In this way the hit will be floated.

\section{METHODS}

The sample is made up of 11 under-20 male players taking part in provincial championship.

The tests carried out before and after the 4-week training period are:

\section{Anthropometrics test}

- Height (cm)

- Weight kg)

- One-handed Reach (cm)

\section{Test physical skills}

- Vertec jump test: the athlete makes a run-up and tries to touch as high as possible with the dominant hand; each athlete makes three jumps, performed after a fair recovery. At the end of the three jumps, we calculate the average value which is taken as the reference value for the test performed. Moreover, by subtracting from the average three jumps the value of the one-handed reach is obtained the value of the differential from the ground of the jump. 


\section{Technical skills test}

- Float serve: each player must perform 5 float serves to a specific area of the field requested by the coach.

\section{Statistical analysis}

Measures of central tendency and dispersion (mean \pm standard deviation) of height, weight and One-handed Reach of a group (11 subjects). Height: 181,5 \pm 5.52; Weight: 76,0 \pm 10.79; One-handed Reach: 232,2 \pm 7,08). A t-test for dependent groups was conducted to check the differences between the pre-post (Vertec Jump and Float Serve) and relative percentages to improvement. The analysis covered basic statistics and percentages for the date considered. All statistical analyses were conducted using Dell's statistical software 13.2.

\section{RESULTS}

Table 1. Anthropometrics data

\begin{tabular}{cccc}
\hline Player & Height $(\mathbf{C m})$ & Weight $(\mathbf{K g})$ & One-handed Reach \\
\hline 1 & 174 & 65,6 & 227 \\
2 & 174 & 60,7 & 225 \\
3 & 184 & 73,8 & 238 \\
4 & 188 & 90 & 244 \\
5 & 185 & 69,2 & 235 \\
6 & 185 & 97,8 & 231 \\
7 & 182 & 73 & 237 \\
8 & 176 & 66,7 & 223 \\
9 & 188 & 85,6 & 231 \\
10 & 186 & 80,5 & 241 \\
11 & 174 & 73 & 222 \\
& 181,5 & 76,0 & 232,2 \\
Average & 5,52 & 10,79 & 7,08 \\
\hline
\end{tabular}

Table 2. Vertec jump test

\begin{tabular}{cccccc}
\hline \multicolumn{2}{c}{ 11-Sept } & \multicolumn{3}{c}{ 09-Oc } & \\
\hline Player & Average & Difference Jump & Average & Difference Jump & $\begin{array}{c}\text { Diff. Jump } \\
\text { Test 1- Test 2 }\end{array}$ \\
\hline 1 & 291,3 & 64,3 & 295,3 & 68,3 & 4,0 \\
2 & 282,0 & 57,0 & 282,7 & 57,7 & 0,7 \\
3 & 299,0 & 61,0 & 304,7 & 66,7 & 5,7 \\
4 & 297,3 & 53,3 & 304,7 & 60,7 & 7,3 \\
5 & 295,7 & 60,7 & 299,3 & 64,3 & 3,7 \\
6 & 291,3 & 60,3 & 292,0 & 61,0 & 0,7 \\
7 & 291,3 & 54,3 & 294,7 & 57,7 & 3,3 \\
8 & 292,7 & 69,7 & 298,7 & 75,7 & 6,0 \\
9 & 285,3 & 54,3 & 286,0 & 55,0 & 0,7 \\
10 & 293,3 & 52,3 & 294,0 & 53,0 & 0,7 \\
11 & 281,3 & $\mathbf{5 9 , 3}$ & 286,7 & 64,7 & 5,3 \\
\hline Average & $\mathbf{2 9 1 , 0}$ & $\mathbf{5 8 , 8}$ & $\mathbf{2 9 4 , 4}$ & $\mathbf{6 2 , 2}$ & $\mathbf{3 , 4 5}$ \\
Standard Deviation & $\mathbf{5 , 5 7}$ & $\mathbf{5 , 0 0}$ & $\mathbf{6 , 9 3}$ & $\mathbf{6 , 2 6}$ & $\mathbf{2 , 3 6}$ \\
\hline \hline
\end{tabular}


T-Test - Significant difference with $p=0,001$ between the two series of jump

\begin{tabular}{|c|c|c|c|c|c|c|c|c|c|}
\hline & \multicolumn{5}{|c|}{ Paired differences } & \multirow{3}{*}{$t$} & \multirow{3}{*}{$g l$} & \multirow{3}{*}{$\begin{array}{l}\text { Sign. } \\
\text { (with } \\
\text { two } \\
\text { tails) }\end{array}$} \\
\hline & & \multirow[t]{2}{*}{ Media } & \multirow{2}{*}{$\begin{array}{l}\text { Dev. } \\
\text { Std. }\end{array}$} & \multirow{2}{*}{$\begin{array}{c}\text { Average } \\
\text { standard } \\
\text { error }\end{array}$} & \multicolumn{2}{|c|}{$\begin{array}{l}95 \% \text { confidence interval } \\
\text { difference }\end{array}$} & & & \\
\hline & & & & & Lower & Higher & & & \\
\hline $\begin{array}{l}\text { Couple } \\
1\end{array}$ & $\begin{array}{l}\text { VAR00001 } \\
\text { VAR00002 }\end{array}$ & 3,48182 & 2,48065 & ,74794 & $-5,14834$ & $-1,81529$ & $4,655^{-}$ & 10 & ,001 \\
\hline
\end{tabular}

Table 3. Float serve

\begin{tabular}{ccccc}
\hline & & 11-Sept & \multicolumn{3}{c}{ 09-Oct } \\
\hline Player & $\mathbf{X}$ & $\mathbf{X}$ & $\mathbf{0}$ & $\mathbf{X}$ \\
1 & 3 & 2 & 3 & 2 \\
2 & 1 & 4 & 3 & 2 \\
3 & 1 & 4 & 3 & 2 \\
4 & 2 & 3 & 3 & 2 \\
5 & 1 & 4 & 3 & 2 \\
6 & 3 & 2 & 3 & 2 \\
7 & 0 & 5 & 2 & 3 \\
8 & 2 & 3 & 3 & 2 \\
9 & 2 & 3 & 3 & 2 \\
10 & 2 & 3 & 2 & 3 \\
11 & 3 & 2 & 4 & 1 \\
Total & 20 & 35 & 32 & 23 \\
\hline Positiveness & 36,36\% & \multicolumn{3}{c}{$\mathbf{5 8 , 1 8 \%}$} \\
\hline
\end{tabular}

Estimating of training effect: $22 \%$

T-Test Significant difference with $p=0,001$ between two series of performances on float serve

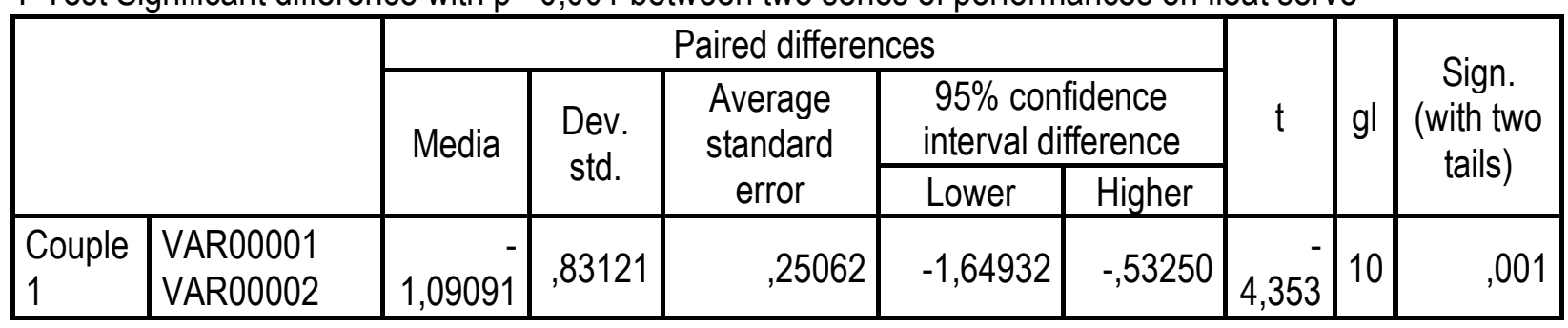

Table 4. Training hours report between pre and post

\begin{tabular}{cc} 
Physical training & $5 \mathrm{~h} 30^{\prime}$ \\
Technique & $9 \mathrm{~h} 30^{\prime}$ \\
of game + friendly matches & $11 \mathrm{~h} 30^{\prime}$ \\
\hline Total & $26 \mathrm{~h} 30^{\prime}$ \\
\hline
\end{tabular}

Table 5. Time dedicated to training of the float serve

Training on the float serve

5 h $45^{\prime}$ 


\section{DISCUSSION AND CONCLUSIONS}

Through the statistical elaboration (test-t with $p<0.05$ ) of the data, it emerged that following the training sessions carried out in the four weeks between pre-post, there was an average increase of $3.45 \mathrm{~cm}$ in the jump differential at the vertec jump test. In the data processing, statisticals and parametrics (test-t with $p$ $<0.05$ ) on the float serve to the specific area indicated by the coach, the serves that have hit the target have gone from 20 to 55 to 32 out of 55 with an increase in the accuracy of this specific serve by $22 \%$. The work carried out is a pilot study for the small sample size (11 players) and for the shortness of the path between the incoming and outgoing tests ( 4 weeks). The test is a tool that allows you to have a very effective periodic control and thanks to the analysis of its results and the feedback received it is possible to relate the performance with the work strategies adopted. Therefore, with this operative strategy, it is possible to identify what can be the best adaptations to be made to the training program that is being administered to the athletes. In order to optimize the monitoring and programming, this study is repeated several times during the competitive season (preparation phase - championship phase - at the end of the championship) to check periodically whether there are improvements in the physical and technical performances.

\section{REFERENCES}

Altavilla, G., \& Raiola, G. (2019). A brief review on physiological commitment in basketball: An interpretative key. Journal of Human Sport and Exercise, 14(1proc), S59-S65. https://doi.org/10.14198/ihse.2019.14.Proc1.07

Altavilla, G., D'Isanto, T., \& Di Tore, P. (2018). Anthropometrics characteristics and jumping ability in basketball. Journal of Human Sport and Exercise, 13(2proc), S385-S392. https://doi.org/10.14198/ihse.2018.13.Proc2.22

Altavilla, G., D'Elia, F., Raiola, G. (2018) A brief review of the effects of physical activity in subjects with cardiovascular disease: An interpretative key, Sport Mont, 16 (3), 103-106. https://doi.org/10.26773/smi.181018

Altavilla, G., Gaetano, R. (2018) Physiological effects of warm-up and problems related to team sports, Sport Science, 11, 83-88.

Altavilla, G., Di Tore, P.A., Riela, L., D'Isanto, T. (2017) Anthropometric, physiological and performance aspects that differentiate male athletes from females and practical consequences, Journal of Physical Education and Sport, 17, 2183-2187.

Altavilla, G., \& Di Tore P.A. (2016). Physical education during the first school cycle: a brief social psychopedagogical summary, Journal of Physical Education and Sport, 16(2): 340-344.

Cirillo, G., Nughes, E., Acanfora, A., Altavilla, G., D'Isanto, T. (2016) Physical and sport education testing by quantitative and qualitative tools in assessment in senior school: A proposal. Sport Science, 9(S1): 97-101.

D'Elia, F. (2019). The training of physical education teacher in primary school. Journal of Human Sport and Exercise, 14(1 proc), S100-S104. https://doi.org/10.14198/jhse.2019.14.Proc1.12

D'Isanto, T., D'Elia, F., Raiola, G., Altavilla, G. (2019). Assessment of sport performance: theoretical aspects and practical indications. Sport Mont, 17(1): 79-82. https://doi.org/10.26773/smj.190214

D'ssanto, T., Di Tore, P. \& Altavilla, G. (2018). Correlation of the anthropometric characteristics and the ability to jump in volleyball. Journal of Human Sport and Exercise, 13(2proc), S393-S400. https://doi.org/10.14198/ihse.2018.13.Proc2.23

D'Isanto, T., Altavilla, G., Raiola, G. (2017). Teaching method in volleyball service: Intensive and extensive tools in cognitive and ecological approach. Journal of Physical Education and Sport, 17(S5): 2222-2227. 
D'Isanto, T. (2016) Pedagogical value of the body and physical activity in childhood, Sport Science, 9 , 13-18.

Di Tore, P.A., Raiola, G. (2012a) Exergame-design and motor activities teaching: An overview of scientific paradigms on motor control, Mediterranean Journal of Social Sciences, 3 (11):119-122.

Di Tore, P.A., Raiola, G. (2012b) Exergames in motor skill learning, Journal of Physical Education and Sport, 12(3): 358-361.

Ferrara, F., Di Tore, P.A., Gaetano, R. (2018). Preliminary work on the testing of power glove applied to volleyball, Journal of Physical Education and Sport, 18(S5): 1986-1990.

Forte, D., \& Altavilla, G. (2018). Preliminary correlation between anthropometric and performance data in volleyball about the transition period, Journal of Physical Education and Sport, 18(S5): 1994-1998.

Raiola, G. (2017). Motor learning and teaching method, Journal of Physical Education and Sport, 17(S5): 2239-2243.

Raiola, G., Di Tore, P.A. (2017). Motor learning in sports science: Different theoretical frameworks for different teaching methods, Sport Science, 10(S1): 50-56.

Raiola, G., D'Isanto, T. (2016). Assessment of periodization training in soccer. Journal of Human Sport and Exercise, 11(1): 267-278. https://doi.org/10.14198//hse.2016.11.Proc1.19

Raiola, G., Altavilla, G., De Luca, C., Di Tore, P.A. (2016). Analysis on some aspects of the service in volleyball, Sport Science, 9 (1): 74-77.

Raiola, G. (2014). Teaching method in young female team of volleyball, Journal of Physical Education and Sport, 14 (1): 74-78.

Raiola, G., Parisi, F., Giugno, Y., Di Tore, P.A. (2013). Video analysis applied to volleyball didactics to improve sport skills, Journal of Human Sport and Exercise, 8(2): 307-313. https://doi.org/10.4100/ihse.2012.8.Proc2.33

Valentini, M., Bernardini, C., Beretta, A., Raiola, G. (2018). Movement and language development as an early childhood twin strategy: A systematic review, Sport Mont, 16 (3), 107-112. https://doi.org/10.26773/smj.181019

\section{(9) $(\mathbb{Q} \Theta \Theta$}

This work is licensed under a Attribution-NonCommercial-NoDerivatives 4.0 International (CC BY-NC-ND 4.0). 